\title{
Fiduciary Obligations and Exculpatory Clauses
}

\author{
COLIN FEASBY*
}

This article considers the relationship between fiduciary and contract law; particular attention is paid to the question of whether exculpatory clauses can limit fiduciary obligations. The article begins with a critical review of recent Supreme Court of Canada cases dealing with fiduciary law in the commercial context and identifies a departure from the Court's earlier contract-dependent mode of analysis. The author then discusses the possibilities and limits of exculpatory clauses in restricting fiduciary obligations between contracting parties. Finally, the article focuses on the practical use of exculpatory clauses in limiting fiduciary liability in commercial joint ventures. Oil and gas Joint Operating Agreements serve as a model for this discussion.
L'auteur examine les liens entre le droit contractuel et fiduciaire, et se demande en particulier si les clauses justificatives peuvent limiter les obligations fiduciaires. Il commence par un examen critique des décisions récentes de la Cour suprême du Canada concernant le droit fiduciaire dans le contexte des relations commerciales et note un changement dans le mode d'analyse de la Cour, autrefois axé sur le contrat. $L$ 'auteur parle ensuite des possibilités et des limites des clauses justificatives concernant la restriction des obligations fiduciaires entre parties contractantes. L'article se penche enfin sur l'usage qui est fait des clauses justificatives pour limiter la responsabilité fiduciaire des entreprises communes. Les accords d'exploitation conjointe du secteur pétrolier et gazier servent de modèle à cette discussion.

\section{TABLE OF CONTENTS}

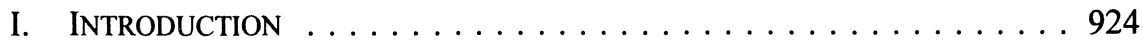

II. THE FIDUCIARY CONCEPT $\ldots \ldots \ldots \ldots \ldots \ldots \ldots \ldots \ldots$

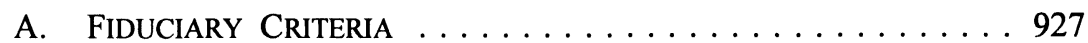

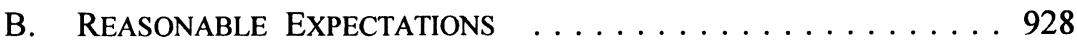

C. A Duty of UtMOST LOYALTY . . . . . . . . . . . . . . 929

III. CONTRACTS AND THE DEFINITION OF THE SCOPE

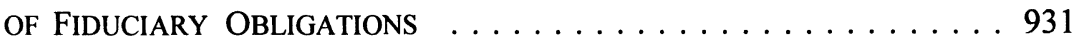

A. CONCURRENT LIABILITY IN LAW AND EQUITY $\ldots \ldots \ldots . .931$

B. CONTRACTS AND THE DEFINITION AND IDENTIFICATION OF FIDUCIARY OBLIGATIONS UNDER THE FIDUCIARY CRITERIA AND REASONABLE

EXPECTATIONS APPROACHES . . . . . . . . . . . . 933

C. CONTRACT-DEPENDENT FIDUCIARY ANALYSIS ........935

IV. FIDUCIARY THEORY AND EXCULPATORY ClAUSES ......... 938

A. CONSENT AND NARROWING THE

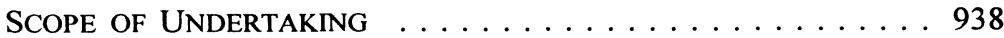

B. GENERAL EXCLUSIONS AND LIMITING

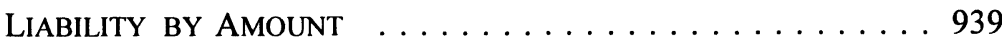

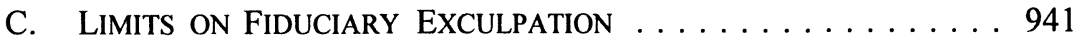

V. CASE STUdY: OIL AND GaS JoINT

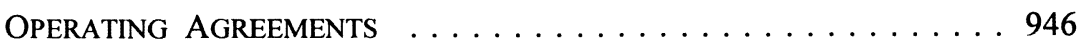

The author would like to thank David Percy for his comments on an earlier draft of this article. An earlier version of this article won first prize in the general category of the 1998 William Morrow Essay Contest. 
A. JoINT OPERATING AGREEMENTS $\ldots \ldots \ldots \ldots \ldots \ldots \ldots 96$

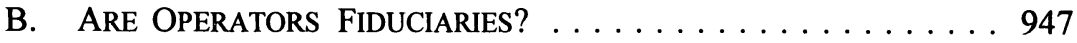

C. FidUCIARY OBLIGATIONS OF OPERATORS $\ldots \ldots \ldots \ldots \ldots .948$

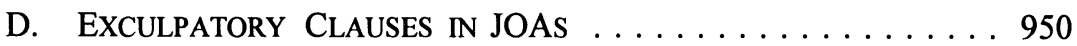

VI. CONCLUSION

\section{INTRODUCTION}

Where there is a breach of fiduciary duty, exclusion clauses ... in the contract have no application. The fiduciary duty transcends these terms and it is abhorrent for contractual terms to abrogate that duty.

per Moore J. in Penner v. Yorkton Continental Securities Inc.

(1996), 183 A.R. 5 at 22 (Q.B.).

[I]t is at least arguable that the contractually agreed exclusion of liability ... should continue to govern any relationship in equity: why should [the plaintiff] derive benefits in equity was for which it not prepared to pay in contract?

per Richardson J.A. in DHL International (NZ) Ltd v. Richmond Ltd [1993] 3 NZLR 10 at 23 (C.A.).

The preceding quotations represent the stark divide in opinion between those who believe that the fiduciary standard is unimpeachable and those who hold freedom of contract sacrosanct. Justification for both views can be found in the case law and in scholarly articles. Which view will prevail in Canada, however, is difficult to predict. The effect of exculpatory clauses on fiduciary obligations is largely dependent on which approach to fiduciary analysis predominates and the interpretive weight given to contracts in that analysis. These questions cannot be answered definitively as recent decisions of the Supreme Court of Canada have thrown the principles of fiduciary law into considerable doubt. Two different analytical frameworks have been employed in recent Supreme Court of Canada decisions: the fiduciary criteria approach and $\mathrm{La}$ Forest J.'s "reasonable expectations" approach. A third contract-dependent approach has not been disavowed and may still have some analytical force. The uncertainty resulting from the Supreme Court's lack of direction has given rise to the concern that fiduciary law will be overused in the commercial arena. ${ }^{1}$ Indeed, the Supreme Court's treatment of fiduciary obligations in the commercial sphere is doubly significant in that it at once leaves the effect of exculpatory clauses open to question and creates a level of uncertainty that makes exculpatory provisions all the more necessary. Although the

The application of fiduciary law in commercial relationships was a concern prior to the advent of the recent Supreme Court approaches and is a matter of concern in other Commonwealth countries where such approaches are not followed. See, for example, M.V. Ellis, "Fiduciary Duty and Joint Business Relations" in A.M. Rock, chair, Special Lectures of the Law Society of Upper Canada, 1990: Fiduciary Duties (Toronto: LSUC, 1991); S. Ongley, "Joint Ventures and Fiduciary Obligations" (1992) 22 VUWLR 265. 
Supreme Court of Canada has adverted to the concerns of commercial parties in obiter dicta, it has not outlined a principled approach to fiduciary relations in the commercial sphere.

Both of the Supreme Court of Canada's favoured approaches suffer from a lack of internal coherence. The Supreme Court of Canada's fiduciary criteria approach is problematic because of the difficulty in defining one of the essential criteria, "vulnerability." Similarly, the Supreme Court of Canada's other approach, the reasonable expectations approach, faces the problem of determining what constitutes a "reasonable" expectation. ${ }^{2}$ The differences between these approaches are significant. They have, however, a more important element of similarity; namely, a contextual rather than contractual approach to determining the existence and scope of fiduciary obligations. Both of these approaches, if applied in the commercial arena, could devalue contracts in the fiduciary analysis. In some circumstances, a contextual approach could frustrate the ability of parties to determine their respective obligations. This is of concern to commercial parties since it could prevent the efficient allocation of risk. Before it is conceded that either the fiduciary criteria or reasonable expectations approach will prevail it must be noted that there is a line of Supreme Court cases in which contracts have played a central - indeed determinative - role in identifying and defining fiduciary obligations. These contract-dependent cases are conceptually inconsistent with the recent approach in the Supreme Court and out of step with the bulk of scholarly commentary. Nevertheless, in recent cases there have been obiter dicta cautions from both factions of the Court against finding fiduciary obligations in the commercial sphere. These dicta cite as authority cases that follow the traditional contract-dependent approach and thereby suggest that this form of analysis may yet have some vitality.

In the face of the uncertain interpretive scope of contracts in the emerging fiduciary framework, it is important to ask whether fiduciary obligations can legitimately and responsibly be limited by contract between sophisticated commercial parties. Even in the more settled arena of contract law, courts have struggled with the idea that parties can relieve themselves of the consequences of their bargains through exculpatory clauses. At various times, courts have used rules of interpretation and the doctrine of unconscionability as grounds to void such clauses in contracts. In the context of excluding fiduciary obligations, there are the further questions of whether contracting out of a fiduciary obligation is itself a breach of a fiduciary obligation and whether public policy requires that there exist a minimum level of duty from which parties cannot be relieved. Despite these obstacles, this article argues that commercial reality must be accounted for in the development of the analytical framework for considering fiduciary obligations. Commercial parties must be allowed to efficiently allocate risk through the use of contractual devices such as exculpatory clauses and fiduciary law, dependent as it is on public policy, must recognize the social utility in permitting such activity.

See L. Smith, "Fiduciary Relationships - Arising in Commercial Contexts - Investment Advisors: Hodgkinson v. Simms" (1995) 74 Can. Bar Rev. 714 at 722. 
The final section of this article is a case study of the use of exculpatory clauses to constrain the application of fiduciary law in oil and gas operating agreements. An oil and gas operating agreement is a paradigm example of a complex contract that creates the possibility of fiduciary obligation. Commonly these agreements contain exculpatory clauses that purport to negate fiduciary liability. Indeed, many of the cases concerning exculpatory clauses and fiduciary obligations have occurred in the context of oil and gas operating agreements. Although cases concerning various operating agreements will be discussed, the focus will be on the 1990 Canadian Association of Petroleum Landmen (CAPL 1990) standard form agreement.

\section{THE FIDUCIARY CONCEPT}

In his seminal article, "The Fiduciary Principle," Austin Scott argued that "a fiduciary is a person who undertakes to act in the interest of another person." ${ }^{3}$ Robert Flannigan also offers a simple explanation: a fiduciary is a person who has been granted access to her principal's assets for a limited or defined purpose. "Assets" and "access" in this sense are defined broadly. "Assets" include authority derived from and proximity to the principal and "access" means the ability to "directly or indirectly acquire the value associated with an asset." ${ }^{4}$ Both Scott and Flannigan's formulations are simple, adaptable, and conceptually coherent. The Supreme Court of Canada, however, has eschewed simplicity; instead opting for vague and conflicting approaches to fiduciary law. Consequently, the question of who or what is a fiduciary is a problem that has bedeviled Canadian courts for the last two decades. The situation is so confused that Justice La Forest once suggested that at a "fundamental level, the principle on which [fiduciary obligations are] ... based is unclear."

Fiduciary obligations can be identified in two contexts. First, fiduciary obligations occur in relationships that are presumptively fiduciary such as trustee-beneficiary, solicitor-client, or director-company. In these "traditional relationships, the characteristics or criteria for a fiduciary relationship are assumed to exist. In special circumstances, if they are shown to be absent, the relationship itself will not suffice." 6 Second, in some cases, the factual circumstances of a relationship will be such that fiduciary obligations are created. The theoretical framework that applies to presumptive fiduciary relationships is the same as that which applies to fact-based fiduciary relationships - the only difference between the two is the onus of proof. As Dickson J., as he then was, noted in Guerin: "It is the nature of the relationship, not the specific category of actor involved that gives rise to the fiduciary duty." ${ }^{7}$ In the discussion that follows, fiduciary obligations arising out of presumptively fiduciary relationships and those identified in particular relationships will be conflated. The Supreme Court's

3 A.W. Scott, "The Fiduciary Principle" (1949) 37 Calif. L. Rev. 539 at 540.

$4 \quad$ R. Flannigan, "Fiduciary Obligation in the Supreme Court" (1990) 54 Sask L. Rev. 45 at 48 [hereinafter Flannigan, "Fiduciary Obligation"]. See also R. Flannigan, "Commercial Fiduciary Obligation" (1998) 36 Alta. L. Rev. 905. 
fiduciary criteria and reasonable expectations approaches are intended to apply to the consideration of fiduciary elements of presumptively fiduciary relationships and to identifying fiduciary obligations in novel contexts.

\section{A. Fiduciary Criteria}

The starting point for the fiduciary criteria approach to fiduciary obligations is Frame v. Smith where Wilson J., in dissent, outlined objective criteria common to all fiduciary relationships:

1) The fiduciary has scope for the exercise of some discretion.

2) The fiduciary can unilaterally exercise that power or discretion so as to affect the beneficiary's legal or practical interests.

3) The beneficiary is peculiarly vulnerable to or at the mercy of the fiduciary holding the discretion or power. ${ }^{8}$

Sopinka J., writing for the majority in LAC Minerals, endorsed Wilson's criteria of fiduciary relationships as a "rough and ready guide" for the identification of fiduciary relationships outside the established categories. ${ }^{9}$ Sopinka J. further explained that vulnerability was the one feature that was "indispensable to the existence of a fiduciary relationship."10

One of the most significant problems with the fiduciary criteria is that the meaning of vulnerability, the most important element, is uncertain. The Supreme Court divided over the meaning of vulnerability in Hodgkinson v. Simms with Sopinka and McLachlin JJ. taking a strict view while La Forest J. questioned the relevance of vulnerability altogether. ${ }^{11}$ In Hodgkinson, a client relied on the representations of his investment advisor in purchasing an interest in a multi-unit residential building (MURB). The advisor did not disclose to his client that he was receiving a commission from the developer for each client that invested in the MURB. Hodgkinson was vulnerable in the sense that he trusted his investment advisor to consider only his interests in advising him. Hodgkinson, however, was not inherently vulnerable - he had the choice to ignore the suggestion of his investment advisor. Sopinka and McLachlin JJ., in their dissenting decision, take a strict view of vulnerability. They emphasize that, "[t]o date, the law has imposed a fiduciary obligation only at the extreme of total reliance."12 Moreover, they state that "the critical question ... is whether there is total assumption of power by the fiduciary, coupled with total reliance by the beneficiary." 13 Finding fiduciary obligations only where there is "total" reliance is consistent with the fact that

Frame v. Smith (1987), 42 D.L.R. (4th) 81 at 136 (S.C.C.).

LAC Minerals, supra note 5 at 62 .

Ibid. at 63.

Hodgkinson v. Simms (1994), 117 D.L.R. (4th) 161 (S.C.C.) [hereinafter Hodgkinson].

Ibid. at 219.

Ibid. at 222 . 
fiduciary duties are a onerous form of obligation and give rise to powerful remedies. From this perspective, in Hodgkinson, the client was not totally reliant on the investment advisor as the investment advisor was not in a "position to exercise unilateral power over the legal or practical interests" of the advisor. ${ }^{14}$ On the facts of the case, according to Sopinka and McLachlin JJ., it would seem that a fiduciary relationship would have arisen if the client had accepted the advice of the advisor "unreflectively and automatically." 15 Under this model of identifying fiduciaries, if the beneficiary retains any degree of autonomy or has resort to any defensive measures such as a contractual penalty, there is little chance of finding a fiduciary relationship.

\section{B. REASONABLE EXPECTATIONS}

The reasonable expectations approach is based on the view that the fiduciary criteria approach has a limited purpose. La Forest J. allows that it might have some utility in identifying new categories of fiduciary relationship, but asserts that it is not useful in identifying fiduciary obligations in the context of particular relationships. When dealing with particular relationships the emphasis on vulnerability can be misleading. Instead, analysis should focus on the connection between the parties that serves as the fount of obligation. ${ }^{16}$ As such, the "reasonable expectations" framework laid out by La Forest $\mathrm{J}$. is a variation of the "undertaking approach" described by Scott. ${ }^{17}$ An expression of the undertaking approach can be found in Hospital Products, a case where a sales agent usurped the business opportunities of its principal. In that case, the High Court of Australia stated that "if one person is obliged, or undertakes, to act in relation to a particular matter in the interests of another and is entrusted with the power to affect those interests in a legal or practical sense, the situation is ... analogous to a trust." 18 The idea of an undertaking as the foundation of a fiduciary obligation is also found in Canadian law in Guerin v. $R$. In the context of the Crown's obligation to aboriginal peoples, Dickson J., as he then was, wrote "where by statute, agreement, or perhaps by unilateral undertaking, one party has an obligation to act for the benefit of another, and that obligation carries with it a discretionary power, the party thus empowered becomes a fiduciary. Equity will then supervise the relationship by holding him to the fiduciary's strict standard of conduct." 19

The idea of an undertaking implicitly forms the basis of La Forest J.'s analysis of "reasonable expectations" in LAC Minerals and Hodgkinson. In LAC Minerals, a case concerning the misuse of confidential information obtained in failed pre-contractual negotiations, La Forest J. wrote for the dissent:

Ibid.

Ibid.

This is the position advanced by A.W. Scott supra note 3 .

This is certainly a debatable point. Though I feel that this is the most logical interpretation of La Forest J.'s words, other commentators have criticized the openendedness of the term "reasonable expectations." See, for example, Smith, supra note 2 at 722.

Hospital Products Ltd. v. United States Surgical Corporation, [1984] 156 C.L.R. 41 at 68 (H.C. Aust.) [hereinafter Hospital Products].

Guerin, supra note 7 at 341 . 
[T]he issue should be whether, having regard to all the facts and circumstances, one party stands in relation to another such that it could reasonably be expected that that other would act or refrain from acting in a way contrary to the interests of that other. ${ }^{20}$

La Forest J. explains again in Hodgkinson, this time for the majority, that where there is an issue as to the existence of a fiduciary relationship, "the question to ask is whether, given all the surrounding circumstances, one party could reasonably have expected that the other party would act in the former's best interests with respect to the subject-matter at issue." 21 What is required to prove the existence of a reasonable expectation, La Forest continues, "is evidence of a mutual understanding that one party has relinquished its own self-interest and agreed to act solely on behalf of the other party."22 In other words, an undertaking is required.

The idea of reasonable expectations forming the basis of the fiduciary analysis leaves little room for consideration of vulnerability. Indeed, La Forest J. observed that vulnerability was inherent in power-dependency relationships and that its existence was of little significance. The idea advanced by Sopinka and McLachlin JJ. that no fiduciary obligation exists where parties who could have protected themselves but failed to do so, is inimical to the reasonable expectations approach. Under the reasonable expectations analysis, where $\mathrm{A}$ and $\mathrm{B}$ have an understanding that gives rise to a reasonable expectation that $A$ has relinquished its self-interest and is to act in the best interests of B, A is a fiduciary. In such a situation, B's vulnerability flows from her reasonable expectation that $A$ will act in her best interests. Whether the vulnerability is total is irrelevant as long as B has a reasonable expectation that A will act in B's interest.

\section{A DuTY of Utmost Loyalty}

The utility and value of a fiduciary relationship is dependent on the fidelity of the fiduciary. The fiduciary, being in a position to divert or appropriate value, is subject to temptation. The possibility of opportunistic conduct on the part of the fiduciary endangers the relationship and attracts the scrutiny of the law. As Ernest Weinrib explains, " $t]$ he wide leeway afforded to the fiduciary to affect the legal position of the principal in effect puts the latter at the mercy of the former, and necessitates the existence of a legal device which will induce the fiduciary to use his power beneficently." ${ }^{23}$ Equity's strict approach to dealing with breaches of fiduciary duty is predicated on the idea of deterrence ${ }^{24}$ and the practical difficulty of establishing

LAC Minerals, supra note 5 at 34 .

Hodgkinson, supra note 11 at 176 . This formulation of "reasonable expectations" echoes the position of P.D. Finn in "The Fiduciary Principle" in T.G. Youdan, ed., Equity, Fiduciaries and Trusts (Toronto: Carswell, 1989) 1 at 5, 46. A good discussion of the weaknesses of the "reasonable expectations" approach written after LAC Minerals but prior to Hodgkinson can be found in Flannigan, "Fiduciary Obligation," supra note 4 at 67.

Hodgkinson, ibid. at 176-77.

E.J. Weinrib, "The Fiduciary Obligation" (1975) 25 U.T.L.J. 1 at 4.

Bray v. Ford, [1896] A.C. 44 (H.L.). 
whether or not a fiduciary acted in good faith. ${ }^{25} \mathrm{~A}$ natural corollary of the privileged position of the fiduciary is that wrongdoing on the part of a fiduciary is unlikely to be detected and, if it is, the motive of the fiduciary will often be difficult to prove. As a consequence, equity requires that any improper profit arising out of a fiduciary relationship be disgorged whether or not the benefit was available to the principal. This strict approach to fiduciaries can be traced to Keech v. Sandford ${ }^{26}$ where a trustee for an infant beneficiary attempted to renew a lease in the infant's name. The lessor refused to renew the lease for the beneficiary, but agreed to enter into a lease with the trustee in his personal capacity. The court held that despite the fact the lessor would not lease the property to the beneficiary, the trustee held the lease in trust for the beneficiary. Keech v. Sandford has been elaborated upon by the English courts ${ }^{27}$ and is echoed in Canadian Aero Service Ltd. v. O'Malley where Laskin J., as he then was, wrote:

\begin{abstract}
Liability of [the defendant] for breach of fiduciary duty does not depend on proof by Canaero that, but for their intervention, it would have obtained the ... contract; nor is it a condition of recovery of damages that Canaero established what its profit would have been or what it has lost by failing to realize the corporate opportunity in question. It is entitled to compel the faithless fiduciaries for answer for their default according to their gain. ${ }^{28}$
\end{abstract}

In cases where compensation is awarded, the high standards required of fiduciaries can be reflected in the measurement of damages. In some instances, the measure of the beneficiary's loss may be made with reference to a date more favourable to the beneficiary than the fiduciary. ${ }^{29}$ In Hodgkinson v. Simms, La Forest J. wrote, "I have no difficulty in resorting to a measure of damages that places the exigencies of the marketplace on the respondent.."30 A similar approach to calculation of damages was taken in Guerin where an unforeseen rise in real estate prices resulted in a large award. ${ }^{31}$ Dickson J., as he then was, justified the award in Guerin by noting that for

J.D. McCamus, "Remedies for Breach of Fiduciary Duty" in A.M. Rock, chair, supra note 1, 57 at 61 .

(1726) 25 E.R. 223.

27 See, for example, Regal Hastings Ltd. v. Gulliver, [1942] 1 All E.R. 378 (H.L.) at 386 where Lord Russel of Killowen wrote:

The rule of equity which insists on those who by the use of a fiduciary position make a profit being liable to account for that profit, in no way depends on fraud, or the absence of bona fides; or upon such questions or considerations as whether the profit would or should otherwise have gone to the plaintiff, or whether the profiteer was under a duty to obtain the source of the profit for the plaintiff ... or whether the plaintiff has in fact been damaged or benefited by his action. The liability arises from the mere fact of a profit having, in the stated circumstances, been made. The profiteer, however honest and well-intentioned, cannot escape the risk of being called upon to account. [1974] S.C.R. 592 at 622.

J.D. Davies, "Equitable Compensation: Causation, Foreseeability and Remoteness" in D.W.M. Waters, ed., Equity, Fiduciaries and Trusts (Toronto: Carswell, 1993) 297 at 302; for example, the approach of the Supreme Court of Canada to measuring damages in Guerin, supra note 7 at 37273, 390-91.

Hodgkinson, supra note 11 at 208.

Guerin, supra note 7. 
a breach of fiduciary duty, "the quantum of damages is to be determined by analogy with the principles of trust law." ${ }^{32}$

The gravity of fiduciary obligations is also evident in the powerful equitable remedies available. ${ }^{33}$ These equitable remedies are flexible and allow the courts to achieve results that reflect the public interest in dissuading fiduciary breaches. The Supreme Court of Canada made this explicit in Soulos v. Korkontzilas where it was observed:

The constructive trust imposed for breach of fiduciary relationship thus serves not only to do justice between the parties that good conscience requires, but to hold fiduciaries and people in positions of trust to the high standards of trust and probity that commercial and other social institutions require if they are to function effectively. ${ }^{34}$

Furthermore, it was remarked that it is "a public concern of the courts to maintain the integrity of fiduciary relationships which the courts of equity supervised." ${ }^{35}$

\section{CONTRACTS AND THE DEFINITION OF THE SCOPE OF FiduCIARY OBLIGATIONS}

\section{A. CONCURRENT LiABILITY IN LAW AND EQUiTy}

A common misapprehension is that the existence of a contract by itself excludes the operation of fiduciary law. Similarly, it has been asserted that if an obligation is created by a contractual term, fiduciary law has no place in remedying a breach unless there is an independent source of fiduciary obligation. These views are reinforced by the lack of a useful definition of vulnerability in the fiduciary criteria approach. Some courts have understood vulnerability to be negated by the existence of a contract and access to contractual remedies. This understanding has a certain intuitive appeal and can be seen in the subtext of many of the decisions where Courts have found fiduciary obligations not to exist. While the exact role of a contract in the definition or negation of fiduciary obligations is open to question, it is clear that a person may be concurrently liable in both law and equity.

The Supreme Court of Canada recognized that concurrent liability may exist in contract and tort in BG Checo International Ltd. v. B.C. Hydro \& Power Authority ${ }^{36}$ and Queen v. Cognos Inc. ${ }^{37}$ La Forest and McLachlin J.J., writing for the majority in $B G C h e c o$, outlined the essence of concurrent liability in the following terms: "In so far as the tort duty is not contradicted by the contract, it remains intact and may be

$32 \quad$ Ibid. at 345 .

33 See generally, McCamus, supra note 25 at 57.

34 Soulos v. Korkontzilas, [1997] 2 S.C.R. 217 at 236.

$35 \quad$ Ibid. at 235.

36 BG Checo International Ltd. v. B.C. Hydro \& Power Authority (1993), 99 D.L.R. (4th) 577

(S.C.C.) [hereinafter $B G$ Checo].

37 Queen v. Cognos Inc. (1993), 99 D.L.R. (4th) 626 (S.C.C.). 
sued upon. ${ }^{\prime 38}$ Further, the majority in $B G$ Checo rejected Iacobucci J.'s contention that where a contract deals expressly with an issue there is no right to sue in tort. The same principles apply where parallel obligations lie in law and equity. As far back as Nocton v. Lord Ashburton, it has been recognized that concurrent obligations in law and equity may exist. ${ }^{39}$ In Nocton v. Lord Ashburton, where the conduct of a solicitor was in question, Viscount Haldane wrote:

a Court of Equity has always assumed jurisdiction to scrutinize [a solicitor's] action. It did not matter that the client would have a remedy in damages for breach of contract. Courts of Equity had jurisdiction to direct accounts to be taken, and in proper cases to order the solicitor to replace property improperly acquired from the client, or to make compensation if he had lost it by acting in breach of a duty which arose out of his confidential relationship to the man who had trusted him. ${ }^{40}$

The principle of concurrent liability in law and equity was affirmed by the Supreme Court of Canada in Canson Enterprises Ltd. v. Boughton \& $\mathrm{Co}^{41}$ and Hodgkinson v. Simms. Viscount Haldane's words in Nocton were echoed by La Forest J. in Hodgkinson where he noted

that the existence of a contract does not necessarily preclude the existence of fiduciary obligations between the parties. On the contrary, the legal incidents of many contractual agreements are such as to give rise to a fiduciary duty. The paradigm example of this class of contract is the agency agreement, in which the allocation of rights and responsibilities in the contract itself gives rise to fiduciary expectations. ${ }^{42}$

The Alberta Court of Appeal interpreted concurrent liability somewhat differently in Luscar v. Pembina, a case where it was disputed whether an Area of Mutual Interest clause in a joint operating agreement created a fiduciary relationship. ${ }^{43}$ In Luscar, Conrad J.A., for the Court, asserted that in order for there to be concurrent actions in law and equity, the equitable obligation must arise independently "in the absence of the specific contractual term that creates the same obligation." ${ }^{.44}$ R.G. Warren, in a comment on Luscar, argued that this is fundamentally inconsistent with the principle of concurrent liability as set out by the Supreme Court of Canada:

Far from requiring the equitable obligation to be independent from the contractual one, the Supreme Court has clearly stated that the conferral of power and discretion on one party has the effect of transforming obligations conferred by the other methods into fiduciary ones... [T] he Supreme Court of Canada does not require that the fiduciary obligation must exist in absence of the specific contractual obligation, in order for there to be concurrent liability. ${ }^{45}$

$B G$ Checo, supra note 36 at 584 .

[1914] A.C. 932.

Ibid. at $956-57$.

(1991), 85 D.L.R. (4th) 129.

Hodgkinson, supra note 11 at 174.

Luscar Ltd. v. Pembina Resources Ltd., [1995] 2 W.W.R. 153 (Alta. C.A.) [hereinafter Luscar]. Ibid. at 173 .

R.G. Warren, "Fiduciary Law in Commercial Relationships: Luscar Ltd. v. Pembina Resources Ltd." (1995) 33 Alta. L. Rev. 677 at 682. 
With respect, considering the principles laid out in Nocton v. Lord Ashburton, Canson v. Boughton, and Hodgkinson, Warren is clearly correct. Fiduciary obligations can though do not inevitably - exist where they derive only from the term of a contract.

\section{B. CONTRACTS AND THE DEFINITION AND IDENTIFICATION OF FIDUCIARY OBLIGATIONS UNDER THE FIDUCIARY CRITERIA AND REASONABLE EXPECTATIONS APPROACHES}

The role of a contract under the fiduciary criteria or under the reasonable expectations frameworks is not determinative of the relationship between the parties a contract is merely one of many facts to be considered in deciding the true nature of the relationship. If the fiduciary criteria were to be applied strictly, a fiduciary relationship could be found irrespective of any contractual terms defining the relationship so long as the factual standing of the two parties was such that it satisfied the criteria. Where A has power and discretion over the practical or legal interests of $\mathrm{B}$, a vulnerable party, A would be a fiduciary. The only safeguard against the expansion of fiduciary obligations under this approach is a very narrow definition of vulnerability. Definitions, however, often loosen over time.

Fiduciary obligations can also be found under the reasonable expectations approach in spite of a governing contract. La Forest J. made this clear in Hodgkinson where he wrote that, in some contractual relationships, "the facts surrounding the relationship will give rise to a fiduciary inference where the legal incidents surrounding the relationship may not lead to such a conclusion." ${ }^{, 46}$ Reasonable expectations may arise from express or implied undertakings including a unilateral representation by one party or unstated understandings between the parties. ${ }^{47}$ Reasonable expectations could also arise out of past dealings between the parties or from industry practice. ${ }^{48}$ The contextual analysis under these approaches is quite different from traditional contract law where the parol evidence rule, subject to exceptions, prevents the consideration of extrinsic evidence that contradicts stated terms.

The British Columbia Court of Appeal considered the effect of a contract under the reasonable expectations approach in Roe, McNeill \& Co. v. McNeill..$^{49}$ In that case, McNeill, an accountant, agreed to transfer his practice to the plaintiff, Roe, McNeill \& Co., and to refrain from practicing accounting within a specified geographical region. The relationship between the parties, however, broke down and McNeill began to practice within the proscribed area and regained many of his former clients. At trial, McNeill was found to be in breach of contract, but not in breach of a fiduciary duty.

Hodgkinson, supra note 11 at 174-75. This is directly contrary to the view expressed by Mason J. in Hospital Products, supra note 18 at 97 where it was held: "The fiduciary relation, if it is to exist at all, must accommodate itself to the terms of the contract so that it is consistent with, and conforms to, them. The fiduciary relationship cannot be superimposed upon the contract in such a way as to alter the operation which the contract was intended to have according to its true construction."

$47 \quad$ Guerin, supra note 7 at 321.

48 See, for example, LAC Minerals, supra note 5 at 38.

$49 \quad$ (1998) 45 B.C.L.R. (3d) 35. 
This conclusion was based on the finding that there was no vulnerability absent the contract and that the parties entered into the agreement at arm's length. The Court of Appeal disagreed noting that "it is the parties' relative positions that result from the agreement, rather than the parties' relative positions preceding the agreement, that should be examined for fiduciary duties." 50 Furthermore, the Court of Appeal concluded:

It would be anomalous indeed that the parties should have stipulated in the contract for one to owe a duty of good faith to the other, and for him to have been found in breach of that contractual duty, but that the law would deprive the other of a remedy for breach of fiduciary duty because he already had a remedy in contract.

In my view the agreement entered into by the parties gave rise to mutual reasonable expectations that McNeill would act for Roe, McNeill's benefit, and that he would not abuse the position of power he held as a result of the agreement entered into. I think that McNeill was subject to a fiduciary duty, independent of the contract, and must be found in breach of it, for the same reasons that he was found to be in breach of the contract. ${ }^{51}$

$M c N e i l l$ follows the reasonable expectations approach and at the same time respects the contract between the parties. This may be explained by the fact that both the text of the contract and the surrounding circumstances of the relationship indicated the existence of fiduciary obligations. The potential difficulty with the reasonable expectations approach arises where contextual factors lead to a finding of a fiduciary obligation where no such standard is contemplated in the contract.

Despite the preference for contextual analysis in the Supreme Court's recent decisions concerning fiduciary law, there are contrary indications in these decisions that suggest that the earlier contract-dependent approach, to be discussed below, may yet be good law in the commercial context. The incongruity of encumbering arm's length commercial dealings with onerous fiduciary obligations was emphasized by Sopinka J. in LAC Minerals ${ }^{52}$ and was reiterated by Sopinka and McLachlin JJ. and La Forest $\mathrm{J}$. in Hodgkinson. Citing earlier cases featuring contract-dependent analysis with approval, La Forest J. wrote:

Commercial interactions between parties at arm's length normally derive their social utility from the pursuit of self-interest, and the courts are rightly circumspect when asked to enforce a duty (i.e. the fiduciary duty) that vindicates the very antithesis of self-interest. ${ }^{53}$

This, of course, begs the question: when are parties at arm's length? La Forest J. avoided this question in Hodgkinson by holding that the relationship between a professional advisor and a client is a distinct species of commercial relationship that is 
characterized by trust and confidence and is not adversarial in the normal sense. ${ }^{54}$ Could similar reasoning apply to joint ventures and other business relationships where parties must co-operate with and trust one another? It is unclear whether the hesitance evident in LAC Minerals and Hodgkinson toward finding fiduciary relationships in the commercial arena is an endorsement of a contract-dependent approach to fiduciary law or merely an intuitive and unprincipled reaction based on the anticipated consequences of a broadening of fiduciary law.

\section{Contract-Dependent Fiduciary Analysis}

Some observers of recent developments in Canadian fiduciary law have expressed concern that the fiduciary concept has been given too wide an ambit. ${ }^{55}$ As discussed in the previous section, the fiduciary principles outlined by the Supreme Court of Canada in recent decisions can be seen to encroach upon the traditional territory of contract law. Commentators and a significant line of authority, however, support the view that the existence of a contract between parties limits the application of fiduciary law in commercial relationships. Professor Finn, for example, argues that "[f]iduciary law is concerned with an imposed standard of conduct. Its standard is not one suited to the generality of contractual relationships and dealings." ${ }^{56}$ Until recently, the Supreme Court of Canada has concurred with this orthodox perspective. This former approach will be discussed in the context of two leading Supreme Court of Canada decisions on fiduciary obligations and commercial contracts: Midcon Oil \& Gas v. New British Dominion Oil Co. Ltd. ${ }^{57}$ and Jirna v. Mister Donut of Canada Ltd. ${ }^{58}$ The more recent application of a variation of contract-dependent analysis in the Alberta Court of Appeal's decision in Luscar v. Pembina will also be discussed. Each of these decisions evince a strong respect for freedom of contract and the ability of commercial parties to define the nature of their own relationships.

\section{MIDCON V. NEW BRITISH DOMINION OIL}

In Midcon, two companies, New British Dominion Oil ("New British") and Midcon Oil \& Gas ("Midcon"), agreed to develop a gas well in southern Alberta under a preCAPL operating agreement with New British as operator and Midcon as a non-operator. The well could not be brought into operation without a sufficient market. Brook, the president of New British, came into contact with a party interested in building a fertilizer plant in the region which would require large amounts of gas; thus, providing a market for gas from the jointly developed well. Brook and New British became involved in the establishment of the company that was to operate the fertilizer plant and purchased shares in the new company for their own benefit. Officials from Midcon inquired as to whether they could obtain shares at the same price as Brook and New

Ibid. at 181.

J.D. McCamus, "Prometheus Unbound: Fiduciary Obligations in the Supreme Court of Canada" (1997) 28 C.B.L.J. 107 and L. Hoyano, "The Flight to the Fiduciary Haven" in P. Birks, ed., Privacy and Loyalty (Oxford: Clarendon Press, 1997) 169.

P. Finn, "Contract and the Fiduciary Principle" (1989) 12 UNSW L.J. 76 at 97.

(1958), 12 D.L.R. (2d) 705 (S.C.C.) [hereinafter Midcon (S.C.C.)].

[1975] 1 S.C.R. 2. 
British and were told that there were none available. Subsequently, Midcon brought an action seeking an accounting of profits against New British alleging that New British had made a profit by virtue of its position as operator.

At trial, Primrose J. held that there was no fiduciary relationship and further noted that, if there was such a relationship, it did not extend to the promotion of the new company. ${ }^{59}$ At the Supreme Court, Rand J., in dissent, held that New British stood in a fiduciary relationship to Midcon. Furthermore, he held that New British had breached its obligation and had gained an unauthorized profit from dealings that were inextricably linked to its role as operator. Locke J., for the majority, concluded that no fiduciary relationship between New British and Midcon existed. This ruling was based on the assumption that the contract between the parties delineated the whole of New British's obligation: "If, therefore, a fiduciary relationship existed between these parties, it either resulted from the terms of the agreement or from what was done pursuant to its terms." ${ }^{160}$ For Locke J., like Primrose J. at trial, a fiduciary obligation could not apply to dealings external to the contract. Central to this conclusion was the presence of a no partnership/entire agreement clause in the operating agreement. ${ }^{61}$ The emphasis on contractual terms in Midcon was endorsed in dicta by Estey J. in Molchan v. Omega where he noted approvingly that "[t] $]$ he importance of the terms of agreement was emphasized by this court in Midcon...." 62

\section{JIRNA V. MISTER DONUT}

Jirna v. Mister Donut concerned a dispute between a franchisee and a franchisor. The franchise agreement required that Jirna, the franchisee, purchase products from suppliers endorsed by the franchisor, Mister Donut. ${ }^{63}$ Unknown to Jirna, Mister Donut received a rebate from the suppliers on products purchased by Jirna and other franchisees. Jirna, after discovering this arrangement, began an action for the recovery of Mister Donut's secret profits. At trial, Stark J. found that the terms of the contract created a relationship between the parties that was "paternal" in nature and akin to a partnership or joint venture despite the presence of a clause that read:

The relationship between the parties is only that of independent contractors. No partnership, joint venture or relationship of principal and agent is intended." ${ }^{64}$

\section{Molchan].}

6.3 Jirna v. Mister Donut (1970), 13 D.L.R. (3d) 645 (Ont. H.C.) (.4 Ibid. at 653. S.C.T.D.) [hereinafter Midcon]. existence of a fiduciary obligation."

Ibid. at 723.

Midcon Oil \& Gas v. New British Dominion Oil Co. Ltd., [1956] 19 W.W.R. 317 at 334 (Alta.

Midcon (S.C.C.), supra note 57 at 722-23. This view is similar to that expressed in the context of a mining joint venture in Noranda Australia Ltd. v. Lachlan Resources NL (1988), 14 NSWLR 1 at 17 where Bryson J. wrote: "The parties' agreement is the prime source for discerning the

Molchan v. Omega Oil \& Gas Ltd. (1988), 47 D.L.R. (4th) 481 at 494 (S.C.C.) [hereinafter 
On appeal, the Ontario Court of Appeal and the Supreme Court of Canada dismissed the trial judge's findings and gave "full effect to the express intention of the terms of the agreement made between the parties on equal footing and at arm's length" and found that there was no fiduciary relationship between Jirna and Mister Donut. ${ }^{65}$

\section{LUSCAR V. PEMBINA}

The Alberta Court of Appeal decision in Luscar v. Pembina was released shortly after the Supreme Court of Canada's decision in Hodgkinson v. Simms. The fact that Hodgkinson was not considered is likely a practical result of the timing of the decision and should not be attributed any substantive meaning. Not surprisingly, given the timing of the decision, Luscar follows the fiduciary criteria approach that was ascendant following the LAC Minerals decision and the narrow approach to vulnerability favoured by Sopinka J. More notable, however, is the attention paid by the Court to the terms of the contract that created the relationship. In this sense, it is reminiscent of the approach seen in Midcon.

Luscar concerned a pre-CAPL operating agreement originally contracted between the predecessors of the parties to the action. Clause 18 of the agreement stated that "where any party acquired or desired to acquire interests in land within the defined area set out in the Area of Mutual Interest (AMI) Clause, written notice and certain information would have to be given to the other parties." ${ }^{66}$ In several transactions between 1971 and 1976, Pembina acquired and pooled lands within the AMI without notifying the other parties to the agreement in writing as required. At trial, it was found that the failure to give notice of the acquisitions within the AMI amounted to a breach of fiduciary duty and a breach of trust. Correspondingly, a constructive trust was declared over Pembina's interests in the lands in question and the net revenues Pembina derived from the lands were also to be held in trust. The Court of Appeal rejected the trial judge's conclusions and found that no fiduciary obligations were created by clause 18 or the AMI clause. Conrad J.A., for the Court wrote:

\footnotetext{
The mere fact a contract imposes responsibilities on one party upon which another relies, does not mean the first party is automatically a fiduciary with respect to the duty created. Moreover, where a specific term of a contract addresses an issue, the contractual remedy may properly redress the wrong, thereby reducing any vulnerability. The parties having addressed the issue specifically by contract, without making the duty to give notice a fiduciary one is also a factor to be considered. ${ }^{67}$
}

Furthermore, she noted, it is "necessary to examine the contractual terms in their entirety to determine whether the parties intended to negate, or reduce, any equitable obligation by the terms of the contract." ${ }^{\prime \prime 8}$

\footnotetext{
65 Jirna v. Mister Donut, [1975] 1 S.C.R. 2 at 3, aff'g (1971), 22 D.L.R. (3d) 639 (Ont. C.A.).

66. Luscar, supra note 43 at 160.

$67 \quad$ Ibid. at 177.

$68 \quad$ Ibid. at 178 .
} 
Unfortunately, leave to appeal Luscar to the Supreme Court of Canada was denied. Luscar would have provided an excellent opportunity for the Supreme Court of Canada to decide whether Midcon-like attention to the terms of a contract, such as that followed by Conrad J.A., is an appropriate method of fiduciary analysis in the commercial context or whether a more contextual approach is preferable.

\section{Fiduciary Theory AND EXCUlpatory Clauses}

Exculpatory clauses are a common device used to allocate risk among contracting parties. The law concerning such clauses in the context of excluding contractual liability, liability for negligence, and trustee liability is well established - though there are still points of debate. ${ }^{69}$ The effect of exclusion clauses on fiduciary obligations, in contrast, has infrequently been considered and is anything but settled. Traditionally, the consent of the principal has been believed to be the key to relieving the fiduciary of liability. This view will be considered in light of the Supreme Court's approaches to fiduciary analysis. Further, the effect of the these approaches will be examined in the context of three main types of exculpatory clause: (1) clauses that purport to limit the duty undertaken; (2) clauses that limit the amount of damages or specify a time limit in which to make a claim; and (3) clauses that seek to exclude liability or consequences of a breach. ${ }^{70}$

\section{A. CONSEnt ANd NARROWIng The Scope of Undertaking}

The most important case to consider in the context of consent and the limitation of the scope of fiduciary obligations is Molchan v. Omega. ${ }^{71}$ Molchan is different from many of the cases discussed in this article in the sense that it deals with a presumptively fiduciary relationship - a partnership. Nevertheless, the case is important because of the interpretive weight given to the partnership agreement in determining the scope of the fiduciary relationship. The partnership agreement gave Omega considerable latitude as the general partner to dispose of partnership assets. The agreement, however, did not explicitly give Omega the power to sell partnership assets to itself or its associates. Despite the fact that self-dealing is one of the classic activities denied to fiduciaries, the Supreme Court of Canada concluded that such a power was implicit in the partnership agreement and deemed that Molchan had consented to Omega's self-dealing.

The majority decision in Molchan is clearly out of step with fiduciary principles. $^{72}$ Genuine consent, not implied acquiescence, is the heart of any limitation on or exemption from fiduciary liability. Scott writes:

See, for example, R. Flannigan, "Hunter Engineering: The Judicial Regulation of Exculpatory Clauses" (1990) 69 Can. Bar Rev. 514 [hereinafter Flannigan, "Hunter Engineering"]. 
Where the fiduciary does an act which would be a breach of his duty as fiduciary if he did not have the consent of his principal, such consent will protect him only if he has in no way taken advantage of his position as fiduciary in procuring the consent. ${ }^{73}$

Consent, in this sense, has always been taken to mean consent to the specific activity in question. Clearly, the partnership agreement in Molchan fell short of this mark. Wilson J.'s dissent more accurately states the proper approach to determining if a fiduciary duty has been excluded. Wilson J. observed that "It would take the clearest of language in the constitutive documents of the partnership to permit such a sale and, in my opinion, no such language is present." ${ }^{174}$ Wilson J. correctly interpreted the contract contra proferentem. Consequently, her decision is a more accurate statement of the law in this area. ${ }^{75}$ Hunt J. in Erehwon Exploration Ltd. v. Northstar Energy Corp. came to a similar conclusion:

To determine the scope of the Operator's fiduciary duty ... one has to look at the contract. While fiduciary obligations can arise in a commercial setting, the scope of the obligations must be interpreted in light of the contractual context. If a fiduciary duty would otherwise arise, and the contractual language specifically negatives this, in my opinion the fiduciary duty must give way to the contractual language the parties have chosen. To follow any other course would create an unwarranted degree of judicial interference in commercial relations. ${ }^{76}$

The requirement of specific consent accords with the reasonable expectations approach insofar as consent to an act of the fiduciary by the principal would negate any fiduciary expectation. Similarly, if vulnerability is the "hallmark" of a fiduciary relationship, informed consent by a beneficiary free from undue influence would seem to vitiate any assertion of vulnerability. The effect of the contextual approach of the Supreme Court may be that consent in the form of a contract is only sufficient if it is consistent with the relationship as a whole. In other words, if reasonable expectations of fiduciary conduct or vulnerability exist notwithstanding the stated terms - perhaps on the basis of conduct subsequent to the contract - then contractual exclusions may not be sufficient to negate fiduciary obligations. A preferable view is that in the commercial sphere it is understood by courts that parties rely on contracts and that reasonable expectations or vulnerability will rarely arise from factors external to the contract. If this is the case, then, as Hunt J. noted, fiduciary obligations must give way to specific contractual provisions narrowing the scope of the undertaking.

\section{B. General EXClusions AND Limiting LiABILITY BY AMOUNT}

General exculpatory clauses and clauses limiting liability by amount may be viewed as simply more extensive exercises in limiting the scope of the obligation

\footnotetext{
Scott, supra note 3 at 541.

Molchan, supra note 62 at 509.

Flannigan, "Fiduciary Obligation," supra note 4 at 69.

Erehwon Exploration Ltd. v. Northstar Energy Corp. (1993), 15 Alta. L.R. (3d) 200 at 249 (Q.B.)

[hereinafter Erehwon] [emphasis added].
} 
undertaken. ${ }^{77}$ Indeed, defining a relationship as not being fiduciary can be seen to be merely a logical extension of specific provisions that permit, for example, self-dealing. As Waddams writes:

\begin{abstract}
There is no substantial difference between assuming a large obligation that is reduced by an exemption clause and assuming a narrower initial obligation. A contractor might undertake to excavate all boulders up to a certain size; or one might promise simply to excavate subject to an exclusion to excavate any solid rock.... Similarly, a restriction of liability may be a perfectly legitimate technique of defining the obligation assumed by a contracting party. ${ }^{78}$
\end{abstract}

Here, however, general exclusions and liability defining clauses will be treated differently for two reasons. First, courts often treat general exculpatory provisions as relieving a party of liability for breach rather than narrowing the initial obligation. ${ }^{79}$ Second, consent is more difficult to establish in cases of general exclusions and clauses limiting liability by amount.

Unlike in the context of provisions narrowing the scope of the undertaking of a fiduciary, general exclusions and liability defining clauses cannot be construed as giving consent to a specific type of activity. At most, these varieties of clauses can be interpreted as a general consent to self-interested behaviour. The "no partnership" clauses in Midcon and Jirna, for example, cannot reasonably be interpreted as giving even general consent as they merely deny a species of relationship to which fiduciary obligations attach. Given that fiduciary obligations may be identified in novel contexts, such a denial of partnership cannot have the effect of negating expectations of specific obligations. Moreover, Professor Waters suggests that in the context of trusts, "[t]he more general the exculpation provision, the more likely it is that the courts will reach the conclusion that the settlor or testator did not intend to relieve the trustee of liability. ${ }^{\prime 80}$ Nevertheless, there is a possibility that a carefully drafted general exculpation targeting fiduciary liability could be effective.

The success of general exclusions, well drafted or otherwise, is dependent on the weight given to contracts in the fiduciary analysis and the clarity of the exculpatory clause. The effect of the relative interpretive weight given to contextual and contractual factors can be observed in the contrast between the trial and appellate decisions in Jirna v. Mister Donut. At trial, Stark J. found that, among other factors, a fiduciary relationship arose out of a pre-contractual representation by Mister Donut to the effect that benefits of the mass purchasing agreement held by Mister Donut would accrue to the franchisee. Under the reasonable expectations approach, Stark J.'s finding might well have stood up in the face of the exculpatory provision. Brooke J.A., using the contract-dependent analysis which was ascendant at the time, held:

Flannigan, "Hunter Engineering," supra note 69 at 526-28.

S.M. Waddams, The Law of Contracts, 3d ed. (Toronto: Canada Law Book, 1993) at para. 465.

Ibid. and Guest, supra note 70 at 14-003.

D.W.M. Waters, Law of Trusts in Canada, 2d ed. (Toronto: Carswell, 1984) at 757. 
[O]n the evidence in this case, I do not agree with the conclusion reached by the trial Judge and the finding of liability on the basis of the fiduciary relationship.... The error, I think, is the result of the characterization by the trial Judge of the relationship between the parties, relying as he did upon some of the provisions of the contract and his interpretation of a representation made in the pre-agreement discussions. ${ }^{81}$

Clauses that define liability by amount are particularly problematic. The object of such clauses is clearly not to give consent to any particular activity rather it is merely to limit the liability flowing from the relationship. At the same time, however, the nature of such clauses suggests that the parties have appraised the total value of the relationship irrespective of the nature of the breach. From this perspective, it is difficult to argue that one of the parties is vulnerable unless they were unfairly induced to enter the contract and, similarly, any party to such a contract would have minimal expectations.

Not surprisingly, there has been almost no consideration of clauses that limit fiduciary liability by amount. The only extant discussion of this type of clause in the context of fiduciary obligations can be found in the dicta of Richardson J.A. of the New Zealand Court of Appeal in DHL International (NZ) Ltd. v. Richmond Ltd. ${ }^{82}$ In this case, goods were shipped from New Zealand to Italy. The bill of lading was to be delivered to a bank by DHL's agent to be held until payment was made by a third party who was the intended purchaser of the goods. Instead of being delivered to the bank, the bill of lading was delivered directly to the third party who claimed the goods and shortly thereafter went bankrupt. At trial the court inferred that the package containing the bill of lading was opened and delivered to the third party, whose name was on the bill of lading, thus violating DHL's fiduciary duty as bailee. DHL claimed that it was protected by a clause that disclaimed liability for "special, incidental or consequential damages" and stipulated that DHL's maximum liability "shall be limited to US $\$ 100.00$." The trial judge found that the breach of fiduciary duty could not be excluded by the contractual term. ${ }^{83}$ On appeal, it was found that no fiduciary duty existed. The Court of Appeal, nevertheless, addressed the question of excluding fiduciary duties saying "it is at least arguable that the contractually agreed exclusion of liability for consequential loss should continue to govern any relationship in equity: why should Richmond derive benefits in equity for which it was not prepared to pay in contract?"84

\section{Limits ON FiduCIARY EXCULPATION}

Moore J.'s assertion that it is abhorrent for fiduciary obligations to be limited by contract $^{85}$ is a view shared by Treitel who suggests that it is not possible to contract

$81 \quad$ Jirna v. Mister Donut (C.A.), supra note 65 at 645.

[1993] 3 NZLR 10 (C.A.).

A. Farrar, "Couriers, Fiduciaries and Exclusion Clauses" (1992) N.Z.L.J. 3 at 4.

DHL International (NZ) Ltd v. Richmond Ltd, supra note 82 at 23.

Penner v. Yorkton Securities Inc. (1996), 183 A.R. 5 at 22. 
out of fiduciary duties. ${ }^{86}$ Some commentators ${ }^{87}$ argue that this position is unnecessarily narrow. Nevertheless, these rejections of the use of exclusion clauses in the context of fiduciary obligations are evidence of a more general uneasiness in the courts concerning the evasion of liability through contract. To deal with the possible unfairness of contracting out of liability, the courts have developed rules of interpretation and the equitable doctrine of unconscionability to prevent exclusion clauses resulting in injustice. It is necessary to consider how the limits on exclusion clauses might apply to general exclusions and limitations of fiduciary liability.

\section{CORE ElEMENTS OF Fiduciary Duty}

The idea that a fiduciary has a core level of duty that may not be contracted out of is notionally related to the concept of fundamental breach ${ }^{88}$ The existence of a core element of a fiduciary's duty is largely a theoretical concern. ${ }^{89}$ Analogies, therefore, must be drawn from trust law. Matthews stated that in English trust law "[i]t is clear that neither liability for fraud or intentional wrongdoing nor duties leading to such liability can be validly excluded, nor powers to commit acts otherwise giving rise to such liability validly included." ${ }^{\circ 0}$ The Law Commission (U.K.) has suggested that "fraud" in this context includes equitable fraud. ${ }^{91}$ This would prevent parties from excluding liability for unconscionable behaviour. ${ }^{92}$

Matthews goes on to suggest that "[i]t is very likely that neither liability for gross negligence nor duties leading to such liability can be validly excluded, nor powers to commit acts otherwise giving rise to such liability validly included. ${ }^{93}$ In Armitage v. Nurse, the English Court of Appeal rejected the assertion that it was impossible to exclude liability for gross negligence, ${ }^{94}$ but affirmed the idea of a minimum core level of duty. The duty "to perform the trusts honestly and in good faith for the benefit of the beneficiaries is the minimum necessary to give substance to the trusts...." ${ }^{95}$ There

G.H. Treitel, The Law of Contract, 9th ed. (London: Sweet \& Maxwell, 1995) at 223: "It is submitted that any contract term by which a person who was under a fiduciary duty attempted to exempt himself for liability for a deliberate breach of that duty would be ... ineffective." He bases this conclusion on a case where a pre-incorporation clause purported to release the promoters of a company from the duty not to make secret profits was held not to exclude fiduciary duties: Gluckstein v. Barnes, [1900] A.C. 240 (H.L.). Treitel's view (as expressed in the 5th ed. of the same text) is cited with approval in R. Lawson, Exclusion Clauses, 2d ed. (London: Oyez Longman, 1983) at 47.

G.M.D. Bean, Fiduciary Obligations and Joint Ventures: The Collaborative Fiduciary Relationship (New York: Clarendon Press, 1995) at 84-85. Discussed below, under heading Rules of Construction. Law Commission (U.K.), Fiduciary Duties and Regulatory Rules: A Consultation Paper, No. 124 (London: HMSO, 1992) at 78 [hereinafter Fiduciary Duties and Regulatory Rules]. P. Matthews, "The Efficacy of Trustee Exemption Clauses in English Law" (1989) Conv. 42 at 54. See also, David A. Steele, "Exculpatory Clauses in Trust Instruments" (1995) 14 Estates \& Trusts J. 216.

91 $\quad$ Fiduciary Duties and Regulatory Rules, supra note 89 at 81. See discussion of unconscionability below under heading Unconscionability. Matthews, supra note 90 at 54 . Armitage v. Nurse, [1997] NLOR No. 229 at para. 35 (C.A.) (QL). Ibid. at para. 31 . 
are very few Canadian authorities that deal with the limitation of trustee obligations. The Canadian position would seem to be the same as the English position save except that a trustee may not be able to exclude liability for gross negligence. In Re Poche, Hetherington J., as she then was, held that "a trustee must be held responsible for any loss resulting from his gross negligence, regardless of any provision in the trust instrument relieving him from such liability."96

\section{RULES OF CONSTRUCTION}

Judges are wary of exclusion clauses as there seems to be something inherently unfair about avoiding the consequences of one's acts. Despite this, it has been recognized that such clauses have commercial utility and should be recognized where the effect was intended by the parties to the agreement. The courts' reluctant acceptance of commercial reality is reflected in rules that govern the interpretation of exclusion and limitation clauses. Such clauses "are to be 'strictly' construed and construed against the interests of the party who drew the document containing them (construction "contra proferentem")." 97 Therefore, to exclude liability, a clause must be "clearly and unambiguously expressed." 98 Waddams cynically notes that the effect of this rule is merely to encourage more precise drafting. ${ }^{99}$ Another effect of this rule is that occasionally a court will strain to uncover ambiguity so that it may employ a strict interpretation against the party seeking to evade liability. However, as L'Heureux-Dubé J. observed, "when the wording of a contract is unambiguous... courts should not give it a meaning different from that which is expressed by its clear terms, unless the contract is unreasonable or has an effect contrary to the intention of the parties." 100

It has been suggested that the contra proferentem rule may be superseded by other considerations in equity. In a discussion of Richmond Ltd. v. DHL International (NZ) $L t d$., Farrar argues that in equity strict interpretation is not enough:

In Equity the question of exclusion clauses is more complex. A simple contract is viewed as a bundle of equities. The exclusion clause is merely one of those equities. It must be weighed against the other competing equities in determining whether or not it is effective to negative liability. ${ }^{101}$

Nevertheless, the New Zealand Court of Appeal made no distinction between exclusions in equity and exclusions in law. ${ }^{102} \mathrm{~A}$ clearly expressed exclusion clause is likely to defeat competing equities unless they amount to unconscionable behaviour. Barring such considerations, the contra proferentem approach to interpretation should clearly apply to the exclusion of fiduciary duties as it does to the exclusion of contractual duties. The advantage of contra proferentem interpretation is that, to an extent, it

Re Poche (1983), 6 D.L.R. (4th) at 55. Implicitly this would suggest that a trustee could be exempted for liability short of gross negligence.

$97 \quad$ Waddams, supra note 78 at para. 467. Ailsa Craig Fishing v. Malvern Fishing, [1983] 1 W.L.R. 964 at 966 (H.L.).

Waddams, supra note 78 at para. 467.

Scott v. Wawanesa Mutual Insurance Co., [1989] 1 S.C.R. 1445 at 1467.

Farrar, supra note 83 at 4.

DHL International (NZ) Ltd. v. Richmond Ltd., supra note 82 at 23. 
protects the unwary while at the same time it allows commercial parties to effectively allocate risk through precise drafting.

Another rule of construction that must be contemplated is the doctrine of fundamental breach. G.M.D. Bean argues that theoretically every breach of fiduciary duty is a fundamental breach. ${ }^{103}$ Since the essence of fiduciary duty is an undertaking to act in the interests of another, any failure to do so results in completely different performance than that undertaken. The House of Lords ruled that the doctrine of fundamental breach is no longer a rule of law, but it remains a rule of interpretation. ${ }^{104}$ As a matter of interpretation, a clause will not be found to exclude a party's liability for an obligation that goes to the heart of a contract unless the wording exempting the party from liability is clearly and unambiguously expressed. Dickson C.J.C. followed the House of Lords' lead saying that "In my view, the courts should not disturb the bargain the parties have struck, and I am inclined to replace the doctrine of fundamental breach with a rule that holds the parties to the terms of their agreement, provided that the agreement is not unconscionable." 105 The doctrine of fundamental breach as a rule of construction adds little to the force of the strict interpretation required by the contra proferentem principle. Dickson C.J.C.'s words, however, are significant because they point to unconscionability as the answer to injustice in the context of exclusion clauses.

\section{UNCONSCIONABILITY}

The doctrine of unconscionability is another possible limitation on the exclusion of fiduciary obligations. The traditional view of unconscionability was that a court could rescind a contract where there had been: "(1) an improvident bargain and (2) an inequality in the positions of the parties." 106 The traditional view, however, is under siege. In Lloyd's Bank v. Bundy, Lord Denning asserted that unconscionability extended to "all cases where an unfair advantage has been gained by an unconscientious use of power by a stronger party against a weaker." $107 \mathrm{He}$ continued by stating that "the English law gives relief to one who, without independent advice, enters into a contract upon terms which are very unfair ... when his bargaining power is grievously impaired ... coupled with undue influences or pressures brought to bear on him by or for the benefit of the other." 108 Lord Denning's formulation has been cited with approval by Canadian courts ${ }^{109}$ and has been reformulated and integrated with the earlier Canadian

Bean, supra note 87 at 87.

Suisse Atlantique Société d'armement Maritime S.A. v. N.V. Rotterdamsche Kolen Centrale, [1967] 1 A.C. 361, aff'd by Photo Production Ltd. v. Securicor Transport Ltd., [1980] A.C. 827 (H.L.). Hunter Engineering Co. v. Syncrude Canada Ltd., [1989] S.C.R. 426 at 455-56 [hereinafter Hunter Engineering]. See discussion of this case and fundamental breach in Flannigan, "Hunter Engineering," supra note 69 at 517-26.

C. Boyle and D. Percy, Contracts: Cases and Commentaries (Scarborough: Carswell, 1994) at 688. [1975] 1 Q.B. 326 at 327.

Ibid. at 339.

For example, Atlas Supply Co. of Canada Ltd. v. Yarmouth Equipment Ltd. (1991), 282 A.P.R. 1 at 28. See also B.M. McLachlin, "The Place of Equity and Equitable Doctrines in the Contemporary Common Law World: A Canadian Perspective" in Waters, ed., supra note 29, 37 at 45-46 where it is suggested that Lord Denning's view has generally been accepted in Canada 
approach by the British Columbia Court of Appeal in Harry v. Kreutziger. ${ }^{110}$ In that decision, Lambert J.A. held that unconscionability was really "a question of whether the transaction, seen as a whole, is sufficiently divergent from community standards of commercial morality that it should be rescinded." 111

The Supreme Court of Canada dealt with the question of unconscionability and exclusion clauses in Hunter Engineering v. Syncrude. ${ }^{112}$ In that case, Dickson C.J.C. suggested that unconscionability is the proper rubric under which to consider the validity of exclusion clauses. ${ }^{113}$ Though it is not explicit, Dickson C.J.C. seems to adopt the community standards approach and Waddams' view that "the rational basis for the control of exemption clauses rests on unconscionability." 14 Ideally this may be the case. In practice, however, the community standards approach to unconscionability suffers from the same definitional problem as the Supreme Court's fiduciary analysis. "Community standards" like "reasonable expectations" or "vulnerability" is not defined with reference to a concrete standard. As such, any inquiry into "community standards" would likely replicate much of the analysis of the contextual factors that give rise to "reasonable expectations" or "vulnerability." If this definitional problem were resolved, unconscionability could prove to be an effective regulator of the exclusion of fiduciary obligations.

The authority of Hunter Engineering is questionable, however, as only five justices took part in the decision and there are differences between the view of unconscionability expressed in the decisions of Dickson C.J.C. and Wilson J.115 Wilson J. did not endorse the principle of unconscionability with the same enthusiasm as Dickson C.J.C. Taking the judgments together, Flannigan concludes that "at a minimum, exculpatory clauses will be regulated by (1) a strict construction of the wording of the provision and (2) an assessment of whether one party took advantage of the severe situational disability of the other party." 116 This more limited view of unconscionability is in accord with the need for certainty in commercial affairs and would provide a more meaningful standard by which to measure exclusions of fiduciary obligations.

\section{BREACH OF FIDUCIARY DUTY AS A LIMIT}

The law of fiduciaries may intervene to limit the application of an exculpatory provision where a fiduciary relationship exists prior to the contract. The application of

despite its subsequent demise in the U.K.

Harry v. Kreutziger (1978), 9 B.C.L.R. 166 (C.A.).

Ibid. at 177.

Hunter Engineering, supra note 105.

Ibid. at 462: "Explicitly addressing concerns of unconscionability and inequality of bargaining power allows the courts to focus expressly on the real grounds for refusing to give force to a contractual term said to have been agreed to by the parties."

$114 \quad$ Waddams, supra note 78 at para. 478.

IIS For a discussion of the differences between Dickson C.J.C.'s decision and Wilson J.'s decision see Flannigan, "Hunter Engineering," supra note 69 at 532-33.

$116 \quad$ Ibid. at 536. 
fiduciary law would depend on two factors. First, whether there was sufficient consent on the part of the principal. Second, whether the exclusion itself constituted a breach of fiduciary duty. Consent of the principal, as discussed above, is sufficient to allow the fiduciary to pursue certain activities in his self-interest. The question that arises where there is a pre-existing fiduciary relationship is whether or not the consent in any way resulted from the power differential in the relationship. Even in the face of consent, in some instances for a fiduciary to endeavour to limit his liability once he becomes a fiduciary would seem to contradict his duty to relinquish his self-interest. For the same reason, public policy demands that fiduciary law would intervene to prevent some categories of fiduciaries from limiting liability at all. A parent, for example, should not be allowed to contract out of her fiduciary obligation to her child.

\section{Case Study: OIl \& Gas Joint Operating Agreements}

Joint Operating Agreements (JOAs) are a salient feature on the landscape of the oilpatch and substantial fortunes are dependent on their terms. The possibility that JOAs have fiduciary aspects has important implications for the oil and gas industry. The imposition of the strict liability required of a fiduciary upon an operator is potentially onerous and could undermine the operator/non-operator relationship. The authors of one leading text have stated:

\footnotetext{
Obviously, if ... a strict fiduciary concept was applied to an oil and gas operator who has a commercial relationship with his other joint-owners, there would be such chaos and uncertainty that no operator would know what profits it was entitled to and whether operating decisions which would result in profit to the operator could be made. While there is an interest in ensuring that a duty of honesty exists in commercial relationships, there is difficulty in ensuring that the fiduciary concept is not applied in a manner which perverts the parties' expectations and intentions. ${ }^{117}$
}

Consequently, many JOAs, including the CAPL 1990, contain provisions that purport to limit fiduciary obligations. It is important to consider whether the present provisions are effective and what modifications might be necessary in light of the preceding analysis of fiduciary obligations and exculpatory clauses.

\section{A. JoINT Operating AGREements}

Joint Operating Agreements (JOAs) are common in the Canadian oil and gas industry. An Operating Agreement has been defined as:

a legally binding document entered into between two or more entities, which provides for the operation and maintenance of a jointly owned oil and gas property, including any or all joint operations conducted thereon. In addition, as a secondary purpose, the joint operating agreement contains

117 N. Bankes \& Bennett Jones Vercherre, Canadian Oil and Gas, vol. 1, 2d. (Toronto: Butterworths, 1993-1998) para. 8.17. 
provisions for the ownership and disposition of leased substances produced from the said joint property. $^{118}$

The CAPL 1990 standard form operating agreement is the industry standard in Canada. CAPL 1990 is the latest in a series of operating agreements originally derived from the AAPL (American Association of Petroleum Landmen) standard form operating agreement. Earlier CAPL forms were issued in 1969, 1971, 1974, and 1981.

Oil and gas exploration and exploitation is a complex and costly business. This enterprise is further complicated by the fact that the rights to oil and gas reserves are frequently divided between neighbours and between co-tenants. The JOA has become one of the preferred ways of reconciling disparate interests in property so that exploration and production may proceed. In addition to the overlapping interests in land that make JOAs necessary, there are a number of strategic reasons to enter into a JOA. Some of these reasons are:

- $\quad$ to spread the risk inherent in all oil and gas ventures among a greater number of prospects;

- $\quad$ to participate in more plays with a given amount of exploration;

- to take advantage of the special expertise of one or more, of the exploration partners;

- to enable non-oil and gas entities to participate in oil and gas joint ventures by the contribution of monies. ${ }^{119}$

\section{B. ARE OPERATORS FiduCiARIES?}

The operator/non-operator relationship created by CAPL 1990 is not a fiduciary relationship per se, but it is a relationship with certain fiduciary aspects. Even if the operator is a fiduciary in a general sense, not every duty owed by the operator will necessarily be fiduciary in character. ${ }^{120}$ This is expressed by Wilson J. in Frame v. Smith where she wrote, "it may be more accurate to speak of relationships as having a fiduciary component to them rather than to speak of fiduciary relationships as such." 121 If a court uses either the fiduciary criteria or the reasonable expectations approach, it is certain that an operator, by virtue of its position as day-to-day manager of affairs, will be found to have some fiduciary obligations even if not all of its obligations are fiduciary. Even if a more contract-dependent approach is used, the operator is likely to be found to have at least some fiduciary obligations. As Paul Finn has written, "the 'operator', ... whatever his precise legal status, is, and because of the

118 T.P. Burns \& J.J. Park, "Joint Operating Agreements and the CAPL Operating Procedure" in Drafting and Structuring Oil \& Gas Agreements (Toronto: Insight Press, 1988) Article 9 at 3-4. Ibid. at 6.

This point is made forcefully by Conrad J.A. in Luscar, supra note 43 at 176-77. Supra note 8 at 98 . 
usual functions he undertakes, the archetypal fiduciary for conflict of duty and interest purposes." 122

The operator has a great advantage over the non-operators in that it controls the daily decision-making, disclosure of information, and has greater familiarity with the operation as a whole. Although there are contractual limitations on the power and discretion granted to the operator, ${ }^{123}$ the operator, by virtue of its superior position as administrator and controller of information, can affect non-operators' practical interests and the exercise of non-operators' contractual rights. Under CAPL 1990, the operator undertakes responsibility for "the management of the exploration, development and operation of the joint lands and the construction, installation and operation of any production facilities for the joint account on behalf of the Joint Operators." ${ }^{24}$ In addition, particular undertakings include keeping records and accounts, ${ }^{125}$ maintenance of title documents, ${ }^{126}$ making reports, ${ }^{127}$ maintaining insurance, ${ }^{128}$ and disclosing information concerning drilling, logging, and well completion and production to the non-operators. ${ }^{129}$ The operator also has the power to dispose of non-operators' production if they do not take in kind. ${ }^{130}$ Under CAPL 1990 it is at least arguable that, as Rand J. wrote of an earlier form of operating agreement, in dissent, in Midcon, "the operator, so developing, exploiting and marketing a jointly owned product for a joint benefit, has reposed in him that reliance and confidence which constitute a trust relation." 131

\section{Fiduciary Obligations of Operators}

The essence of the fiduciary obligation is the "no conflict rule" 132 and the specific duties of fiduciaries can be seen as applications or extensions of that rule. ${ }^{133}$ Finn has identified eight types of proscriptive fiduciary duties, ${ }^{134}$ of which he suggests the following four are of "regular significance" in the context of oil and gas joint operations: ${ }^{135}$

P. Finn, "Fiduciary Obligations of Operators and Co-Venturers in Natural Resource Joint Ventures" (1984) AMPLY 160 at 162 [hereinafter "Fiduciary Obligations of Operators"].

For example, the requirement for the approval of expenditures over $\$ 25,000$ (CAPL 1990, cl. 301(b)).

CAPL 1990, cl. 301(a).

CAPL 1990, cl. 305.

CAPL 1990, cl. 309.

CAPL 1990, cl. 310.

CAPL 1990, cl. 311.

CAPL 1990, cl. 701-707.

CAPL 1990, cl. 610 .

131 Supra note 57. See also the remarks of Stratton J.A. in Bank of Nova Scotia v. Société General (Canada) (1988), 87 A.R. 133 at 139: "It [the Operator] was in a fiduciary position with respect to the management of the product and ultimately the distribution of the revenues therefrom."

Bean, supra note 87 at 43 n. 123

Ibid. at 42

P.D. Finn, Fiduciary Obligations (Sydney: Law Book, 1977) at 201-202.

The Law Commission of England has identified four rules of fiduciaries: (1) the "no conflict rule";

(2) the "no profit" rule; (3) the undivided loyalty rule; and (4) the duty of confidentiality.

(Fiduciary Duties and Regulatory Rules, supra note 89 at 32). 
(1) the duty of confidence;

(2) the conflict of duty and interest rule;

(3) the rule regulating purchases by persons occupying confidential positions; and

(4) the rule governing the misuse of trust property. ${ }^{136}$

Using the "no conflict" principle and Finn's four duties, a non-exhaustive list of fiduciary breaches that may arise in a JOA relationship can be outlined. Each of the following has been the subject of litigation in the context of joint ventures:

(1) misuse or unauthorized disclosure of information obtained on behalf of the joint account to a third party; ${ }^{137}$

(2) unauthorized self-dealing; ${ }^{138}$

(3) unauthorized changes in the nature of the project; ${ }^{139}$

(4) failure to disclose information as required; ${ }^{140}$

(5) undisclosed acquisitions within territory covered by an Area of Mutual Interest (AMI) clause, ${ }^{141}$

(6) undisclosed dealings external to, but related to, the $\mathrm{JOA} ;{ }^{142}$

(7) breach of marketing provisions ${ }^{143}$; and

(8) misuse of funds or joint property. ${ }^{144}$

In each of these areas, an opportunity exists for there to be a conflict between the operator's self-interest and the operator's duty to the non-operators.

136 Finn, supra note 134 at 162 . The other four proscriptive obligations of a fiduciary are (1) not to be in a situation of differing duties; (2) not to inflict harm on an employer's business; (3) not to use undue influence; and (4) not to take accretions, such as renewals of leases: Finn, ibid. at 78-81. See, for example, McLeod and More v. Sweezey (1944), 2 D.L.R. 145 (S.C.C.) where the plaintiff engaged the defendant to stake mineral claims for asbestos. The defendant failed to find asbestos, but found chrome. The defendant failed to disclose his finding and later staked claims to the chrome in his own name.

$138 \quad$ Molchan, supra note 62.

139 See, for example, Prairie Pacific Energy v. Scurry-Rainbow Oil (1994), 147 A.R. 261 (Q.B.) where there were unauthorized perforations of a well during re-completion. Mason $J$. found that the unauthorized perforation changed the fundamental nature of the venture from re-completion to exploration (ibid. at 281).

140 See, for example, Passburg Petroleums v. San Antonio Explorations Ltd. (1987), 57 Alta. L.R. (2d) 57 (Q.B.) where a more expensive directional well was drilled instead of a conventional well.

141 See, for example, Luscar, supra note 43 and Erewhon, supra note 76.

142 See, for example, Midcon, supra note 59 and McLeod and More v. Sweezey, supra note 138.

143 See, for example, Act Oils Ltd. v. Pacific Petroleum Ltd. (1975), 60 D.L.R. (3d) 658 (Alta. App. Div.); Erehwon, supra note 76; Trilogy Resources Corp. v. Dome Petroleum Ltd. (1990), 76 Alta. L.R. (2d) 140 (Q.B.).

144 See, for example, Bank of Nova Scotia v. Société General (Canada), supra note 131; and Sturrock v. Ancona Petroleums Ltd. (1990), 75 Alta. L.R. (2d) 216 (Q.B.). Also, note that CAPL 1990, which was not the subject of either of these decisions, deems joint funds to be held in trust (cl. 507). 


\section{ExCUlPatory Clauses in JOAS}

In the U.S., where courts generally apply a contract-dependent approach to fiduciary obligations, the AAPL Model Form agreement has been largely successful in excluding fiduciary duties. The CAPL agreement contains similar, but less forceful, provisions to those found to exclude fiduciary duties in the AAPL form. The inclusion of a clause specifically negating all fiduciary obligations like that in the AAPL form and other strategies for excluding fiduciary duties have been put forth by influential observers of the CAPL agreement as answers to the fiduciary conundrum.

\section{AMERICAN OPERATING AGREEMENTS}

When considering oil and gas agreements it is often prudent to consider the treatment of similar agreements in the United States. Many oil and gas documents, including operating agreements, have their origins in the United States and have been analyzed by American courts. The United States courts that customarily deal with operating agreements generally follow a contract-dependent analytical framework similar to that found in Midcon when considering the issue of fiduciary obligations. In Frankfort Oil Company v. Snakard a clear statement of the U.S. view ${ }^{145}$ of fiduciary relationships arising out of operating agreements was made:

The relationship so created was fiduciary in character and required the utmost good faith on the part of both parties. The extent and effect of such relationship is determined by the written agreements between the parties defining and delineating the powers and rights of each. In such a situation it is presumed that they delegated all the powers they wished to confer upon each other and witheld all powers or authority not affirmatively delegated. The relationships between them are controlled by the terms of their agreements voluntarily made. ${ }^{146}$

In a more recent case, the U.S. Court of Appeals, 5th Circuit elaborated on this explaining that: "the Texas courts have made it clear that in order for a court to read additional provisions [including fiduciary obligations] into the contract, the implication must clearly arise from the language used, or be indispensable to effectuate the intent of the parties. It must appear that the implication was so clearly contemplated by the parties that they deemed it unnecessary to express it."147

Midcon-like clauses that purport to deny a specific relationship such as a partnership or a joint venture are common in American operating agreements. ${ }^{148}$ Such denials were originally inserted into operating agreements to try to insulate the participants from third party liability. They have, however, been largely unsuccessful in achieving this end. ${ }^{149}$ There has been little judicial consideration of the effect of such clauses

See, for example, Andrau v. Michigan Wisconsin Pipe Line Co., 712 P.2d 372 at 376 (Wyo. 1986). 279 F.2d 436 at 443 (10th Cir. 1960). A similar statement is made in British American Oil Producing Company v. Midway Oil Company, (1938) 82 P.2d 1049.

Norman v. Apache, 19 F.3d 1017 at 1024 (10th Cir. 1994).

See C. Lane \& C.J. Boggs, "Duties of Operator or Manager to its Joint Venturers" (1984) 29 RMMLI 199 at 229-36.

Ibid. at 230. 
on the obligations between operator and non-operator and the precedents that exist are ambiguous and unpersuasive. In Oklahoma Co. v. O'Neil, the Oklahoma Supreme Court held that a clause disclaiming any intent to create a partnership or similar relationship was ineffective because it had been agreed to under conditions of fraud. ${ }^{150}$ There is no indication how the clause would have been interpreted had the contract not been induced by fraud. A Louisiana court gave effect to a similar clause that disavowed any intent to create a "joint venture, fiducial obligation, or similar, though innominate relationship." 151 It would seem that the effect of such clauses is uncertain given the paucity of jurisprudence on the question.

Despite the lingering questions about clauses denying the existence of relationships that carry fiduciary obligations and fiduciary obligations themselves standard operating agreements in the U.S. continue to contain such provisions. Indeed, there is an explicit denial of fiduciary obligations in Article VII-A of the AAPL Form 610-1989. The terms are unequivocal:

\begin{abstract}
The liability of the parties shall be several, not joint or collective. Each party shall be responsible only for its obligations, and shall be liable only for its proportionate share of the costs of developing and operating the contract area... It is not the intention of the parties to create, a mining or other partnership, joint venture, agency relationship or association, or to render the parties liable as partners, co-venturers or principals. In their relations with each other under this agreement, the parties shall not be considered fiduciaries or to have established a confidential relationship but rather shall be free to act on an arm's length basis in accordance with their own respective self-interest, subject, however, to the obligation of the parties to act in good faith in the dealings with each other with respect to the activities hereunder. ${ }^{152}$
\end{abstract}

This clause differs from the clauses in the above cases in that it appears to specifically apply to the liability between the parties as opposed to being aimed at defeating third party claims. Moreover, the clause substitutes a duty of good faith which, as will be discussed below, may cause the courts to be more sympathetic because it does not show a desire to evade liability altogether.

The effect of blanket denials of fiduciary relationships may or may not be effective in the U.S., but several authorities indicate that more modest provisions that substitute a lower standard of conduct are effective. In Dime Box Petroleum Corporation v. Louisiana Land and Exploration Company, the U.S. Court of Appeals, 10th Circuit, considered whether or not the AAPL 610-1977 Model Form Operating Agreement created a fiduciary duty. ${ }^{153}$ The Court found that a fiduciary obligation did exist under Colorado law, but that the obligation was modified by Article $\mathrm{V}$ of the operating agreement which stated that the "operator has no liabilities to nonoperators for effectively precluded a fiduciary duty arising. This decision was vacated, 431 P.2d 445 (Okla. 1967), because one of the judges had accepted a bribe. A new opinion reversing the initial finding was issued: 440 P.2d 978 (Okla. 1968). 
liabilities incurred except for those arising from the operator's gross negligence or wilful misconduct." "154 The Court concluded that "the parties contracted for a standard to measure [the] operator's conduct which is different than that applicable to a fiduciary." 155 Provisions similar to Article V in other joint operating agreements limiting liability except for gross negligence or wilful misconduct have been held to be effective. ${ }^{156}$ In these cases, the courts were satisfied that the parties bargained for the lower standard of conduct and, presumably, from this they inferred that the parties had placed a value on the level of liability that was accounted for in the contract.

\section{CAPL 1990}

An operating agreement (non-CAPL) with a limitation clause similar to the Dime Box clause was considered in United Canso Oil \& Gas v. Washoe Northern Inc. and found to protect an Operator from liability short of gross negligence. ${ }^{157}$ The clause read:

6. (a) Joint-Operator's right of action against Managing-Operator is strictly limited to action for loss, damage or costs caused by the gross negligence or wilful misconduct of Managing-Operator in the performance of, or in the failure to perform, Managing Operator's obligations under this Agreement. $^{158}$

The defendants (Husky Oil) argued that this clause had the "effect of ... circumscrib[ing] fiduciary or trust duties." ${ }^{159}$ The decision, however, is notable for its lack of discussion of fiduciary principles; Hutchinson J. was more concerned with the definition of gross negligence. This approach indicates implicitly that he accepted the defendants submission that fiduciary duties could be limited by contract. Indeed, Justice Hutchinson held that "With respect to the Husky defendants, ... they are protected by clause 6 of the Operating Agreement." ${ }^{160}$ Hunt J., as she then was, distinguished United Canso from the facts before her in Erehwon where obligations under an AMI clause were in issue on the grounds the CAPL wording is different from that of clause $6 .^{161}$ Hunt J.'s emphasis on the significance of the wording suggests that despite her decision in Erehwon she would allow a general exclusion of liability arising from a breach of fiduciary duty if the clause was carefully drafted and clearly was intended to have that effect.

The CAPL agreement contains two clauses that are analogous to those found in the AAPL form. The first, clause 401, purports to exempt the operator from liability to the non-operator(s) except where the loss is one for which the operator is obliged to carry

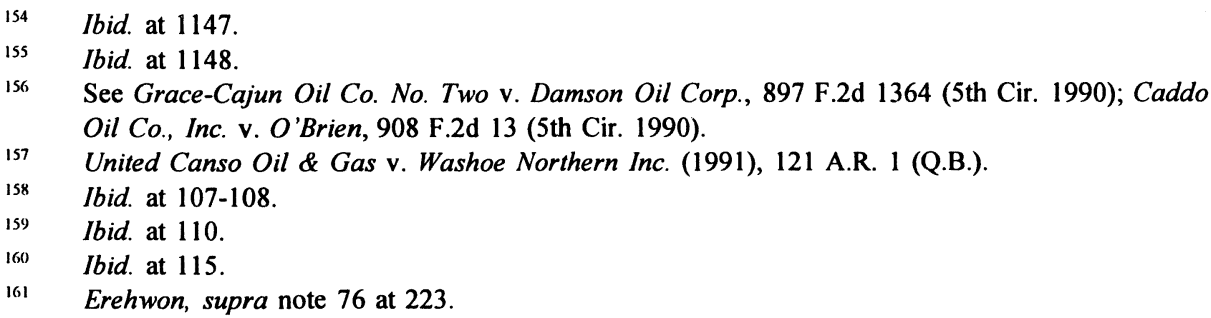


insurance or where the loss is attributable to gross negligence or wilful misconduct. This clause was considered by Justice Hunt in Erehwon. Hunt J. avoided the question of whether the clause substituted the lower standard of conduct in place of a fiduciary standard; rather, she looked to the intention of the parties. She suggested that the clause was concerned with third party losses and did not apply to relations between the operator and non-operator. ${ }^{162}$ Furthermore, she held that the clause did not apply to accounting duties as that would give the operator more control than she thought was intended by the parties. ${ }^{163}$

The other exclusion provision in the CAPL agreement is essentially a milder version of AAPL Article VII-A. Like the AAPL provision, it can be interpreted as being aimed at third party claims. The clause states:

1501. PARTIES TENANTS IN COMMON - The rights, duties, obligations and liabilities of the parties hereunder shall be separate and not joint or collective, nor joint and several, it being the express purpose and intention of the parties that their interests in the joint lands and in the wells, equipment, production facilities and property thereon held for the joint account shall be held as tenants in common, subject to the modification of the incidents thereof that are approved in this Operating Procedure. Nothing herein shall be construed as creating a partnership, joint venture or association of any kind or as imposing upon any party, any partnership duty, obligation or liability to any other party. ${ }^{164}$

CAPL cl. 1501 is not conceptually different from the "no partnership" clauses found in Midcon ${ }^{165}$ and Jirna v. Mister Donut. ${ }^{166}$ From the perspective of the reasonable expectations and fiduciary criteria approaches, it is clearly insufficient to preclude fiduciary obligations. The denial of partnership does not negate a reasonable expectation of selfless conduct nor does it speak to the issue of vulnerability. In Bank of Nova Scotia v. Société General (Canada), it was held that "the presence of this section does not negative the existence of a fiduciary duty on the part of the operator toward the non-operators. This section defines the relationship of all participants in the venture inter se; it does not override the fiduciary obligation imposed on the operator when one considers the whole agreement." 167 There is no reason to suspect that this finding will not stand under the reasonable expectations or fiduciary criteria approaches. The most noticeable difference between cl. 1501 and Article VII-A of the AAPL 1989 form is that there is no specific denial of fiduciary obligations. It is uncertain if such an addition would have affected the Court of Appeal's interpretation of the clause.

The inadequacy of CAPL exclusions is manifest in the prominence with which the issue of contracting out of fiduciary obligations in operating agreements featured in a group of papers presented by influential commentators at a recent Legal Education Society of Alberta seminar. ${ }^{168}$ Several suggestions as to how to modify CAPL so as 
to effectively control fiduciary obligations were made in the seminar papers. W.J. Hope-Ross put forth the idea that $\mathrm{cl} .1501$ be modified to read "Nothing herein shall be construed as creating ... any ... obligation or liability whether fiduciary or not."169 This suggestion is notably different from the existing clause in that it is concerned with fiduciary liability not partnership or other status. A more aggressive clause was proposed, in a paper prepared by J.F. Newman and presented by John Ballem. The following clause, it was suggested, could be attached to CAPL or other oil and gas agreements:

The parties hereby expressly acknowledge and declare that the obligations that either party hereto owes to the other arising out of the performance of this Agreement are specifically set forth herein, and that this Agreement is intended by the parties to be a complete and final statement of their respective mutual rights, duties and obligations. The parties hereto further acknowledge and agree that, except as set forth expressly herein, there are no obligations, tortious, fiduciary, trust, implied or otherwise, owed by the one to the other and that any act taken by a party hereto which is not expressly prohibited pursuant to the provisions hereof is hereby declared to be specifically permitted. ${ }^{170}$

The Newman/Ballem clause is very clear with respect to fiduciary obligations. Indeed, the permission to do anything not expressly prohibited, however, could be a source of more anguish than fiduciary obligations in the first place. In a different paper on the subject of confidentiality agreements, Ballem suggested a different tactic; that parties receiving information attempt "to exclude remedies for breach that are not specifically provided for, in particular, exclude the existence of a fiduciary relationship and exclude the remedies available at equity." ${ }^{171}$ All of these suggested methods to exclude liability show that there is both concern about fiduciary liability and uncertainty with how to deal with it.

\section{A Suggested Clause fOR EXCluding Fiduciary Obligations IN CAPL}

Before any attempt is made to exclude fiduciary obligations, it is important to recognize that in some aspects of the operator/non-operator relationship the threat of fiduciary liability may in fact make the agreement more efficient and effective. With this in mind, the first step is to consider what activities typically forbidden to fiduciaries are necessary to the agreement. Activities where the parties decide the operator should have the power to act in a self-interested way should be explicitly permitted; thus narrowing the scope of fiduciary obligation. This is already, to some extent, accomplished by the CAPL 1990 terms that allow limited self-contracting. ${ }^{172}$ If a general exculpatory clause is still deemed necessary, it is important to consider the analytical framework used to identify fiduciaries. An exculpatory clause must negate any reasonable expectation of fiduciary conduct and undermine any perception of vulnerability. Furthermore, an exculpatory clause must be clear and fair so as not to run

\footnotetext{
169 "Practical Aspects of Oil and Gas Agreements Within the Current Law" in ibid. 3.1 at 3.2.

"Contracting Out of Fiduciary Relationships," ibid., 4.1 at 4.9.

"Confidentiality Agreements," ibid., 5.1 at 5.12.

CAPL 1990, cl. 303.
} 
afoul the strict rules of construction and the doctrine of unconscionability. To do this an exculpatory clause must:

- demonstrate that the parties have adverted to the possibility that the relationship or elements of the relationship are fiduciary in nature;

- make clear the consent of the subordinate party to the lowered standard of conduct;

- $\quad$ show that the exclusion of liability has been bargained for.

A simple version of such a clause might read:

The co-venturers, for good consideration and fully advised of their legal rights including the potential fiduciary aspects of the proposed relationship, hereby agree to limit their liability with respect to one another. The co-venturers agree that the operator shall not be liable for acts, including those amounting to breach of fiduciary duty, unless there is wilful misconduct.

Although this clause is designed to obviate fiduciary obligations arising under the Supreme Court'sreasonable expectations and fiduciary criteria approaches, the particular circumstances of any given relationship may frustrate its purpose.

\section{Conclusion}

The Supreme Court has voiced a concern that fiduciary obligations should not proliferate in the context of arm's length commercial relationships. The concern has been echoed by the Alberta Court of Appeal and other courts. Nevertheless, no principled or practical framework has been laid out to satisfy this concern. As a result, the risk of fiduciary obligations arising in unforeseen circumstances is a real source of concern in commerce. This unease is particularly evident in industries, such as the oil and gas industry, where relationships with collaborative elements are commonplace. The challenge facing the Supreme Court of Canada is to establish a principled exception in the commercial arena without undermining its theoretical approach to fiduciary obligations in general. Other common law countries have avoided this conundrum by refraining from expanding fiduciary doctrine beyond its traditional limits. Clearly, in Canada, the clock will not be turned back - there is every indication that fiduciary law will continue to be used to right wrongs that otherwise escape the sanction of the law. A forward-looking solution must be found.

Exculpatory clauses are perhaps the most obvious tool available to commercial parties determined to circumscribe fiduciary obligations. Such clauses, however, can have no more effect than the contract of which they are a part. When a contextual analysis is used, a contract is just one of a number of factors comprising a relationship and may or may not be found to reflect the reasonable expectations of the parties. Perhaps the most logical way for the Supreme Court to remain faithful to its expansive fiduciary principles while limiting their effect in the commercial arena is to find a way 
to give effect to exculpatory clauses. To this end, what is required is a recognition that commercial parties typically reduce their respective rights and obligations to contractual form. Judicial notice of this fact could give rise to a presumption that when courts are dealing with commercial parties the entirety of the relationship is embodied in the contract. A presumption of this sort would only allow a contextual analysis where it could be shown that the parties did not intend the entire relationship to be defined in the contract could be rebutted. This would enable the courts to give effect to exculpatory clauses subject to any core level of duty that must be retained as a matter of public policy, the rules of interpretation, unconscionability, and pre-existing fiduciary obligations. 